Japanese Yearbook on Business History - 1996 / 13

\title{
Problems of Technology Choice Faced by the Private-Sector Steel Industry in Prewar Japan
}

\section{Nippon Steel Pipe's Steel Manufacturing Integration and the Introduction of Converters}

\author{
Yōichi KoBAYAKaWA \\ Chübu University
}

7 He PURPOSE OF THIS STUDY is to consider the process in which, and the background against which, Nippon Steel Pipe (Nippon Kōkan), the largest private steel manufacturing company in prewar Japan, handled the problem of selecting technology under a wartime regime by integrating steel manufacturing and introducing the use of converters. There are five major steel manufacturers in Japan today; if one sets aside Nippon Steel, one of whose antecedents was the government-owned Yawata Iron and Steel

* This paper is a revised and partly rewritten version of my article "Nippon Kōkan ni okeru keiei kakushin - shigen setsuyakugata no kakushin" [Managerial innovation in Nippon Steel Pipe: A resource-conserving type of innovation], in Tsunehiko Yui and Jurō Hashimoto, eds., Kakushin no keiei shi [A business history of innovation] (Yūhikaku, 1995). 
Works, Nippon Steel Pipe was the only one of the four remaining manufacturers to have settled on integrated steel manufacture even before the war. In addition, Nippon Steel Pipe was the only one of these five to be using converters in its operations before the war. Such enterprise actions were technology choices made in order to cope with the problem of the supply of raw materials for steel manufacturing in Japan during the war, but that is not all. One can also think of them as anticipations in prewar times of the directions Japan's steel industry would take after the war.

Nippon Steel Pipe originally started off at the end of the Meiji Period as a steel manufacturer and rolled steel producer whose aim was to be the first manufacturer in the country to produce for the steel pipe market. It introduced what was at that time in Japan the most up-todate pipe manufacturing methods and set about producing seamless steel pipes. At that time, by seeking raw materials for steel manufacturing through the importation of Indian pig iron, it opened up a new supply source of raw materials. Next it aimed at being self-supporting in regard to such raw materials by carrying out a vertical integration into the pig-iron manufacturing sector, so that before the war it ended up being the first of the private enterprises to develop in the direction of integrating pig iron and steel manufacturing. The fact that this integrated factory was a "littoral-type" factory is also noteworthy. Once focused this way, Nippon Steel Pipe immediately introduced converters (Thomas converters); this was also chosen as a means to cope with the problem of scrap iron, another raw material for steel manufacturing. And the introduction of these converters acted as the stimulus that would lead Nippon Steel Pipe to be the pioneer after the war in introducing the basic oxygen furnace process (what is referred to as the Linz-Donawitz process), the most revolutionary method in the steel manufacturing industry in the whole world.

In the pages that follow I propose to discuss these various enterprise actions within Nippon Steel Pipe from its beginnings right up to the wartime period. I do not hesitate to carry the discussion right back to the company's beginnings, because by doing so it will be possible to obtain an even better grasp of the background to our main topic. 
Nippon Kōkan (KK), or Nippon Steel Pipe (Co., Ltd), is a steelmaker and rolled steel company founded in June 1912 for the purpose of manufacturing steel pipes, by the then authority on steel technology in Japan, Kaichirō Imaizumi, and by Motojirō Shiraishi, a son-in-law of Söichirō Asano (founder of the Asano zaibatsu). The company was attempting to manufacture, by means of original technology, seamless steel pipes - an achievement that was epoch-making in Japan at that time. Despite the innovativeness that marked its steel pipe operations, however, I shall limit any remarks I have to make in regard to those operations to just what is necessary for our purposes, and we shall pay more attention to the fact that the company sought a new supply source for pig iron, a raw material used in steel manufacturing, in India.

To begin with, the first person in Japan to take notice of steel pipe operations was not Imaizumi but Kihachirō Ōkura (founder of the Ōkura zaibatsu). ${ }^{1}$ But what Ōkura had in mind were welded steel pipe manufacturing operations, and when he made enquiries at Yawata Iron and Steel Works about whether it would be possible to obtain a supply of the skelp needed as raw material for such operations, this led to Imaizumi's becoming involved in steel pipe operations. (The enquiry is thought to have been made around May 1908.) Imaizumi, who at the time was the head both of the rolled steel department and the engineering department at Yawata, replied to the enquiry by saying that Yawata had no plant producing the rolled steel used in skelp manufacturing, nor did it have any plans to build such a plant. Shortly afterwards, however, Imaizumi was sent to Europe in connection with a draft of Yawata's "Second Expansion Plan," and on that occasion he noticed seamless steel pipes, which were being produced by the Mannesman pipe manufacturing method that was spreading throughout Germany. Upon his return to Japan he advised Ōkura about the superiority of this method and on the future prospects of seamless steel pipes. Asked by Ōkura to cooperate in Ōkura's planning of

${ }^{1}$ This account of the events leading to the establishment of the company is based on Kaichirō Imaizumi, Nippon Kōkan Kabushiki Kaisha sōgyō nijūnen kaikoroku [Recollections of twenty years of Nippon Kōkan operations], 1933. 
steel pipe operations, Imaizumi agreed, and in April 1910 he quit Yawata Iron and Steel Works. While he was drafting the plans for Ōkura's steel pipe operations, he helped set in motion preparations for establishing a company.

At first Imaizumi planned to link these steel pipe operations with pig-iron manufacturing operations Ōkura was planning to set up in China. The idea was that, if Ōkura could set up a pig-iron manufacturing plant in China, they could build a steel manufacturing plant there, export the steel ingots to Japan, and use them as the raw materials for steel pipes. The problem was, Ökura's plans for the plant in China dragged on and on, with the result that the plan to build a steel pipe plant in China foundered over the problem of raw materials, and Okura himself came to have a negative attitude toward the steel pipe operations. Imaizumi gives as one of the reasons for Ōkura's negative attitude the fact that prospects of being guaranteed official demands from the Navy had not materialized, despite Ōkura's efforts in that direction.

Imaizumi's resolve to get into the steel pipe manufacturing business was unshakable, however. With the idea of conducting steel ingot production domestically, he switched his policy to one of planning on building an integrated steel manufacturing/rolled steel (steel pipe) factory, but then he came face-to-face with the problem of obtaining the pig iron needed as the raw material for steel manufacturing. I shall say more about the question of obtaining pig iron later, but at this point suffice it to say that, in Imaizumi's view, it would have been impossible to obtain a sufficient supply of it domestically, and yet use of imported pig iron was out of the question because of its dearness. It was then that Imaizumi adopted the idea of giving priority to pig-iron manufacturing operations. (This was early in 1911.) Planning the matter carefully with an old acquaintance of his who had a keen interest in domestic manufacturing of pig iron, Kichiemon Kishimoto, Imaizumi decided to establish a pig-iron manufacturing company, and went ahead with preparations.

But as he was doing so he learned from an old friend, Motojirō Shiraishi, that it was possible to import from India, on a continuing basis, low-cost pig iron. At this point Imaizumi persuaded Shiraishi to join him, and it was agreed to establish a steel pipe manufacturing company, with Shiraishi the key man in charge of the company. 
At the same time the plans with Okura for steel pipe operations were officially terminated, while the plans for Kishimoto's iron manufacturing plant were proceeded with separately.

As can be seen from the circumstances leading up to the establishment of Nippon Steel Pipe, the very establishment of the company was delayed by the bottleneck produced by the problem of raw material supply, and the way this bottleneck was handled prefigured the directions the company would later take in its technology choices.

Let us now take a closer look at the problem of raw pig iron.

Reference was made to the point earlier, but Imaizumi's thoughts on the subject of the problem of raw pig iron can be summed up as follows. ${ }^{2}$ First of all, pig iron imported from England was expensive, and using it was out of the question. Secondly, most of the pig iron produced domestically was produced by Yawata Iron and Steel Works, and it was for private use only and not sold on the open market. Thirdly, there was some pig iron produced by the privately owned Kamaishi Iron Works, but it was almost entirely foundry pig iron, and also expensive. All these judgements of Imaizumi were well founded and sound.

Instead of having Nippon Steel Pipe directly involved in importing Indian pig iron, Imaizumi decided to import it through Kishimoto \& Co. (Kishimoto Shōten), a steel wholesaling company located in Osaka and managed by Kichiemon Kishimoto. Within the same year (1911) after he had learned about Indian pig iron from Shiraishi, Imaizumi was sending personnel to India, where a permanent contract was entered into with Bengal Iron Co. for pig iron, with sole-agency rights in Japan invested in Kishimoto \& Co. ${ }^{3}$ Kishimoto $\&$ Co. then began importing pig iron produced by Bengal Iron Co. ("Bengal pig iron") into Japan before the year was out. ${ }^{4}$ I do not think we need go into the particulars of further developments in this area or of the directions taken by Kishimoto \& Co. The only thing I would like to point out is that, within a few years, there was an increasing

${ }^{2}$ Ibid., pp. 57-58.

${ }^{3}$ Ibid., pp. 66-67.

${ }^{4}$ Osamu Nagashima, Senzen Nihon tekkō sangyō no kōzō bunseki [Structural analysis of prewar Japan's steel industry] (Meneruba Shobō, 1987), pp. 159-61. 
amount of pig iron being imported into Japan from India. In 1913 Mitsui \& Co. (Mitsui Bussan) began importing pig iron produced by the Tata Iron and Steel Co., and then in 1918 Suzuki \& Co. (Suzuki Shōten) entered into a long-term import contract with the same Tata Iron and Steel Co. ${ }^{5}$ As we shall see later, it was this increase in pig iron imports that finally created the situation that led Nippon Steel Pipes to head in the direction of self-sustenance in pig iron.

At any rate, Nippon Steel Pipe thus pioneered the development of a new supply source for raw pig iron in Japan's steel industry. The company would "use mostly Indian pig iron ... from its establishment, through the 1910s and into the 1920s." 6 While the figures for sources of pig iron purchases cannot be determined with any certitude for the first year of operations, from the mid-1910s the picture is clearer: the proportion of Indian pig iron purchases in 1913 was $79 \%$, in 1914 it was $62 \%$, and in 1915 it was $73 \% .{ }^{7}$

Nippon Steel Pipe got off to a good start. Operations had barely begun in April 1914 when World War I broke out, and this led to a huge boom for Japan's steel industry. In response to the swelling demand and soaring market prices, the fledgling company embarked on a policy of large-scale expansion of plant facilities and a diversification in steel products. Thus, along with an increase in quick succession of steel manufacturing capacity (beginning with the addition of two 20ton open-hearth furnaces in 1916, followed by two more of the same in 1917, and then three more of the same in 1918), it also responded to the increased demand for various types of steel products by adding to its steel pipes production the production of steel rods (bars) and section steel (angles). ${ }^{8}$ And even within the category of steel pipes, it developed the manufacture of pipes of varying diameters.

${ }^{5}$ Ibid.

${ }^{6}$ Nippon Kōkan, ed., Niłppon Kökan Kalushiki Kaisha yonjünen shi [Forty years of Nippon Steel Pipe] (Nippon Kōkan, 1952), p. 863. (Hereafter abbreviated as Forty Years)

${ }^{7}$ Ibid., and also Nagashima, Structural Analysis of.Japan's Prewar Steel Industry, p. 114.

${ }^{8}$ Seiiichi Kojima, Nippon Kökan Kalnushiki Kaisha saljūunen shi [Thirty years of Nippon Steel Pipe] (Nippon Kōkan, 1942), pp. 160-61. (Hereafter abbreviated as Thirly Years) 


\section{ESTABLISHING AN INTEGRATED SYSTEM OF PIG-IRON AND STEEL MANUFACTURE}

Once off and running as a steel and rolled steel manufacturer, Nippon Steel Pipe's next big challenge was becoming self-sustaining in the raw materials needed in steel manufacture. In the steel industry in Japan at that time one of the most conspicuous features, from the perspective of production structure, was the insufficient quantity of pig-iron production as compared with steel production - in other words, the imbalance between pig iron and steel. On the individual industry level, except for Yawata Iron and Steel Works, the principal steel enterprises were either firms that emphasized pig-iron production or steelmaking and rolled steel firms that had no pig-iron division at all. In contrast to the other pig-iron manufacturers, which belonged to a large coalition formed around Yawata Iron and Steel Works, Nippon Steel Pipe would achieve a reverse integration into the pigiron sector. That is to say, when in 1936 it put into operation its first blast furnace, the company would before long develop into a truly integrated pig-iron and steel manufacturer.

The end of World War I led to a complete turnaround in business, bringing a sharp drop in the steel market, so that steel production from that period on until the occurrence of the Manchurian Incident in 1931 fell into a long recession, during which Nippon Steel Pipe, along with other steel companies, experienced a painful deterioration and stagnation in business conditions. ${ }^{9}$ In October of the year that followed the reactionary panic of 1920 the company quickly reduced by half its capital of $¥ 21,000,000$, got rid of fixed assets, and carried out other adjustments in its operations (in the very next year, however, it doubled its capital again and returned to the $¥ 21,000,000$ level). But from the mid-1920s on a combination of things like the aggressive exporting ("dumping") of steel by the United States and Europe and the steady fall in the domestic price of steel products consistently hurt the company's business results, and business either got worse or, at best, stagnated. Under these conditions the company took various measures to rationalize the business, such as increasing production in order to lower costs and taking

${ }^{9}$ This account of trends in the company after World War I is based principally on Kojima, Thirly Years, pp. $170 \mathrm{ff}$. and Forly Years, pp. $79 \mathrm{ff}$. 
steps to make operations more efficient, but eventually, in November 1931, the company once again was forced to reduce its capital (reducing $¥ 21,000,000$ by $¥ 4,200,000$ ) and write off fixed assets and losses.

After the Manchurian Incident there was a quick turnaround in conditions. The quick recovery in business conditions within industrial circles in general and the increase in military demand led to a rapid growth in demand for steel, while at the same time the flood of imported steel products that had been oppressing the steel industry in Japan for such a long time suddenly became a small trickle, thanks to a drop in the yen exchange rate. As a result, conditions in the steel industry also made a notable recovery.

Now, behind Nippon Steel Pipe's carrying out of a vertical integration into the pig-iron manufacturing sector there lies a close connection with a long string of events, starting with the pig-iron cartel formed in 1926, the huge hike in pig-iron tariffs imposed in 1932, and the founding of Nippon Steel Company (Nippon Seitetsu Kaisha). Let us study this series of events, connecting it with Nippon Steel Pipe's motives for entering into the blast furnace sector.

The hike in pig-iron tariffs was made for the principal purpose of putting an end to the importation of Indian pig iron. As I mentioned earlier, it was none other than Nippon Steel Pipe that led the way in importing Indian pig iron. As can be seen from Table 1, Indian pig iron, which was cheaper and of better quality than domestically produced pig iron, was imported into Japan in increasing quantities, particularly after World War I, and it maintained an overwhelming presence in the domestic market. The pig iron market is divided into pig iron for steel-manufacturing use and pig iron for castings; in the former category imported Indian pig iron represented over 60 percent of the market. The Japanese pig-iron manufacturers, being competitively at a disadvantage, formed an association of pig-iron manufacturers after World War I and adopted cooperative action for a while, but in June 1926 they officially set up a Pig Iron Association (Sentetsu Kyōdō Kumiai) and embarked on volume regulation and price regulation.

Even prior to this, in 1925 pig iron tariffs were again deferred (having been deferred once before in 1921), but a hike was already in the political pipelines, and in 1924 and 1925 discussions were already being 
Table 1. Volume of Imports of Pig Iron, by Principal Countries (Unit: 1,000 tons)

China England India America $\begin{gathered}\text { Total } \\ \text { (incl. other countries) }\end{gathered}$

$\begin{array}{rrrrrl}1913 & 60 & 99 & 82 & 0 & 265 \\ 1914 & 55 & 60 & 31 & 3 & 169 \\ 1915 & 83 & 37 & 38 & 1 & 167 \\ 1916 & 102 & 32 & 63 & 4 & 232 \\ 1917 & 110 & 5 & 61 & 25 & 232 \\ 1918 & 158 & 18 & 7 & 13 & 225 \\ 1919 & 95 & 45 & 29 & 36 & 283 \\ 1920 & 141 & 59 & 48 & 36 & 349 \\ 1921 & 76 & 23 & 34 & 1 & 227 \\ 1922 & 129 & 10 & 101 & 1 & 328 \\ 1923 & 98 & 6 & 137 & 0 & 346 \\ 1924 & 165 & 8 & 160 & 0 & 442 \\ 1925 & 48 & 8 & 153 & 0 & 316 \\ 1926 & 4 & 8 & 228 & 0 & 400 \\ 1927 & 6 & 7 & 261 & 0 & 473 \\ 1928 & 31 & 8 & 310 & 28 & 569 \\ 1929 & 57 & 9 & 411 & 30 & 654 \\ 1930 & 35 & 4 & 214 & 2 & 406 \\ 1931 & 78 & 4 & 150 & 1 & 399 \\ 1932 & - & 3 & 118 & 0 & 444 \\ 1933 & - & 3 & 172 & 0 & 641\end{array}$

Note: As regards the pig iron from China, it has been said that "almost all of it is purchased on the basis of a special connection with the government-owned Yawata Iron and Steel Works and is almost monopolized by that company, with almost none of the material making its way into the general market." (See source below, p. 295.)

Source: Bunji Nakura, Nihon tekkōgyō shi no kenky $\bar{u}$ [Study of the history of Japan's steel industry] (Kondō Shuppan, 1984), p. 294. The original source for this source was the Mining Bureau, Ministry of Commerce and Industry, Seitetsugyō sankō shiryō [Reference materials on the steel industry], 1935. 
held in Japan between the informal association of pig-iron manufacturers and the companies importing Indian pig iron in regard to maintaining prices. ${ }^{10}$

It was approximately around this time that Nippon Steel Pipe began groping its way towards the building of blast furnaces. According to the research findings of Osamu Nagashima, in the year prior to the formation of the Pig Iron Association cartel (in 1925, therefore), the company was already calculating the costs and income to be expected should two blast furnaces (with a daily production capability of 230 tons each, for a yearly output of 160,000 tons). As well, in 1928 and in the following year separate estimates were made. ${ }^{11}$ Nevertheless, no decision was made at this time regarding the construction of blast furnaces.

The protective tariff on pig iron had been put off twice after the end of World War I, but in June of 1932 the legislation was finally enacted into law. Pig iron tariffs were raised in one stroke by 260 percent. As far as Nippon Steel Pipe was concerned, this meant a completely changed situation, for now the pig iron cartel, acting within the protection of the tariff barriers, could make full use of its regulatory tactics.

Nippon Steel Pipe did not act immediately to build blast furnaces, however. While the detailed particulars are not clear, it seems that in December of that year is was still discussing some form of coalition with the pig-iron manufacturer Kamaishi Mining Co. (Kamaishi Közan). ${ }^{12}$ It would seem that the company was planning to achieve pig-iron self-sustenancy through a union of some sort with Kamaishi Mining. But then when in April 1933 the government passed the Nippon Iron and Steel Corporation Law, creating a large combine of Yawata

${ }^{10}$ See Ken'ichi Iida, Shūji Ōhashi, and Toshirō Kuroiwa, eds., Gendai Nihon Sangyō hattatsu shi IV: Tekkō [History of the development of modern Japanese industry, 4: Steel] (Kōjunsha, 1969), pp. 265 ff., and Tetsuji Okazaki, "Sentetsu Kyōdō Kumiai" [Pig Iron Association ], in Jurō Hashimoto and Haruhito Takeda, eds., Ryōtaisenkanki no Nihon no karuteru [Cartels in Japan between the two world wars] (Ochanomizu Shobō, 1985, pp. $23 \mathrm{ff}$.

11 Osamu Nagashima, "Nihon Kōkan Kabushiki Kaisha no kōro kensetsu" [Nippon Steel Pipe's blast furnace construction], Shishi kenkyū Yokohama [City-histories research, Yokohama], No. 2 (1988), pp. 3-6.

${ }^{12}$ Ibid., p. 7. 
Iron and Steel Works and private steel companies (in the earliest proposals there were to be eleven private steel manufacturers in the combine, but in the end only seven actually took part), the company acted with great speed. In the same month it submitted to the Ministry of Commerce and Industry a request for approval to build blast furnaces. But then the plans in the submission were changed, and in October the submission obtained approval as regards its applicability under the Iron Manufacture Encouragement Law. ${ }^{13}$ Once this was obtained it was not long before, in January of 1935, construction was begun first of all of a 350-ton blast furnace, which was completed in June of 1936; operations got under way in December, and Nippon Steel Pipe had entered its pig-iron integration mode. As an outsider that had decided against joining the pig-iron manufacturers' association, it was no doubt necessary to take such a self-protective step in order to assure itself of a supply of raw pig iron.

When it branched out into the blast furnace business, thought had been given to such matters as the land where the smelter plant was to be located and the efficient conveyance of the raw iron ore and coal. The eventual concept was based on the idea of a "littoral-type steel mill."14 Nippon Steel Pipe's steel manufacturing/rolled steel factory (Kawasaki Works) had been built at the seaside in Kawasaki City, Kanagawa Prefecture, because that was considered a convenient place for taking in the pig iron and scrap iron delivered from domestic and overseas suppliers, also having in mind the places where the finished products would be consumed. And the new pig-iron manufacturing factory (Ōgimachi Works) was situated on land adjacent to

${ }^{13}$ Ibid., pp. 12-15.

${ }^{14}$ After World War II Kawasaki Steel's Chiba Iron and Steel works, built in 1954, were the first littoral-type integrated steel plants in postwar Japan, and they are often referred to as being the models for steel mills in Japan after them. The factory faces the ocean on three sides. In other words, they were laid out in the most efficient manner, in that "the plant was fitted out in an efficient manner along three docks, with stress laid on conveyance, so that iron ore and coal went in through the front, scrap went in from the south side, and products were unloaded from the north side," and within the mill conveyance was done mostly by means of belt conveyors, with everything "from raw materials to the finished products traveling the shortest course possible." See Kawasaki Jükögyō Kabushiki Kaisha shi (hon shi) [History of Kawasaki Heavy Industries (Main history), 1959, pp. 936-37. The expression "littoral-type" means that the factory has wharves where ships carrying raw materials and finished products can dock, and also that the factory is laid out in a rational way, as described above. 
the steel/rolled steel manufacturing factory. Wharves where ships conveying raw materials and fuel were able to dock were made (with a mooring capacity of two 10,000-ton ships and one 4,000-ton ship), and adjacent to this place a blast furnace was built, and at the same time a system was installed whereby the pig-iron, in its molten state, could be transported by rail directly to the steel manufacturing factory. Later, when they added other blast furnaces, they lined them up in a straight line in front of the wharf; quite obviously this was also inspired by the idea of maintaining an efficient layout. ${ }^{15}$ What this all means is that we can safely say that the positioning of its factories by Nippon Steel Pipe had, before the war, taken a form that was very close to the littoral-type steel mill that became a feature of the layout of Japanese steel manufacturing factories in the period after World War II.

To return to the historical progression of events: soon after it had built its first blast furnace, Nippon Steel Pipe was involved in building more. In February 1937 it had its second blast furnace in operation (400 tons), in May of 1938 it had its third in operation (600 tons), ${ }^{16}$ and in 1939 it was starting the construction of its fourth blast furnace (also 600 tons). In this manner Nippon Steel Pipe succeeded in achieving a degree of self-sustenance in raw pig iron. Of all the pig iron the company used, the proportion occupied by pig iron that it had produced itself came to 90 percent in 1937, and from the following year it achieved almost complete self-sufficiency. ${ }^{17}$ Along with the construction of blast furnaces, naturally, construction also went ahead on a coke factory and a by-products factory. Needless to say, the savings on fuel and the recovery of by-products helped the integrated steel manufacturing system prove its effectiveness in the company's lowering of the manufacturing cost of its steel ingots. In this sense, the company had developed into a truly integrated steel manufacturer. In view of the fact that in a short time the government would adopt as its steel industry policy under the wartime economy regime the establishment of integrated steel manufacturing systems and would press for increased production systems, Nippon Steel Pipe's

15 Thirty Years, pp. 305-306, and Forty Years, p. 183.

${ }^{16}$ Thirly Years, pp. $180 \mathrm{ff}$.

${ }^{17}$ Forly Years, p. 864. 
entry into the pig-iron manufacturing sector certainly had gone ahead in a form that would anticipate national policies.

Now, while it is quite accurate to say that the company developed into an integrated steel manufacturer, still, as long as a company adopts the open-hearth process for manufacturing steel, it will also need to use, besides pig iron; large amounts of scrap iron. In Japan the steel manufacturing method in use till then had mainly been the open-hearth process, ${ }^{18}$ and the country had always had to be dependent upon large amounts of imported raw scrap iron. After the Manchurian Incident, for example, Japan's domestic output of steel from 1932 to 1936 showed an increase of 120 percent, but during this period the amount of pig iron used as a raw material for steel had increased by only 90 percent (so it was less than the increase in steel output), while the amount of scrap iron used had increased by 150 percent. ${ }^{19}$ In other words, the increase in steel output during this period was made possible by the increase in the amount of scrap iron used. And roughly half of this scrap iron was dependent upon imports, of which from 60 to 70 percent were imports from the United States. Even Nippon Steel Pipe was similarly reliant upon imports: 50 to 60 percent of its purchased scrap iron was imported material. We can be sure, then, that Imaizumi, as well as Shiraishi, were quite aware of the problem when they planned their integrated steel operations, and that, in order to free themselves from dependence upon imported scrap iron, they were thinking about introducing some method of making steel that did not require scrap iron. It was for this reason that, very soon after they opted for blast furnaces, they would introduce what was known as the Thomas converter.

${ }^{18}$ In the government-owned Yawata Iron and Steel Works, the company had used, right from its inception in 1901, both the open-hearth and the converter (Bessemer converter) processes, but in 1927 it had suspended its converter operations. Because lowphosphorus steel could not be produced by the Bessemer converter, its uses were limited. In order to solve this problem, at Yawata Iron and Steel Works they developed a process that combined the open-hearth furnace and converter to eliminate even more phosphorus from converter steel ingots, and they actually made use of the process, but the method made a rise in the cost of steel manufacture unavoidable. See Yawata Seitetsusho hachijünen shi: Bumon shi jökan [Eighty years of Yawata Iron and Steel Works: Division histories, part 1] (1980), pp. 63-69.

${ }^{19}$ The Metal Bureau, Ministry of Commerce and Industry, ed. Seitetsugyō sankō shiryō [Steel industry reference materials] (1943), pp. 28-29, 308-309. 
THE INTRODUCTION OF THE

THOMAS CONVERTER STEEL MANUFACTURING PROCESS: ATTEMPTS TO GET AWAY FROM THE OPEN-HEARTH PROCESS

Along with pushing on with integrated pig-iron manufacturing, another move that was, from the point of view of technology choice, an epoch-making step was Nippon Steel Pipe's introduction of the Thomas converter process of steelmaking as part of a plan to get free of the restraints of the open-hearth process. This enterprise action, which formed, as it were, "one set" with integrated pig-iron manufacture, was destined to show its effectiveness very quickly within developments in the wartime regime, but this was not its only merit. It must also be pointed out that the technology accumulated in the course of using this converter steelmaking process was an important factor that enabled Nippon Steel Pipe to be one of the earliest after the war to take note of the LD (Linz-Donawitz) converter and to introduce it into Japan.

The Thomas steel manufacturing method was invented by the Englishman Sydney Thomas in 1877. What it amounted to was a "method of removing phosphorus in the Bessemer converter." ${ }^{20}$ The reason this method was not developed very far in the country of its origin, England, but instead spread and developed in Germany, was that in the latter country a great deal of phosphorus-containing iron ore was produced, and thus in the steel manufacturing stage it was very important to remove phosphorus.

\footnotetext{
${ }^{20}$ For this account of the process in which the Thomas steel manufacturing method was invented and the technology involved, I principally consulted Tetsu no rekishi [The history of steel], Morihito Nakazawa's translation of Ludwig Beck's book (Tatara Shobō, 1972), vol. 5, pt. 3, pp. 78 ff., and Shin'ichi Nakazawa's three-part article, "Wakaki kyosei Tōmasu" [The young bright star, Thomas], in Tekkōkai [World of steel] (1957), nos. 6 , 7, and 8. With a Bessemer converter it is true that scrap iron and iron ore are not needed in the steelmaking process, and as a steel manufacturing method that required no fuel (it used the silicon in the pig iron as its heat source) it was an epoch-making advance over the open hearth, but it was not a suitable method for refining pig iron that contained a lot of phosphorus. The Thomas method of steel manufacturing, on the contrary, not only retained the good points of the Bessemer converter, it also was a steel manufacturing method that made the removal of phosphorus possible. That is to say, by blowing air from the bottom of the converter it was possible to produce a reaction between the oxygen in the air and the phosphorus inside the pit iron, and thus to get the amount of heat needed for refinement. Using the phosphorus particles inside the pig iron as a heat source, it removed those phosphorus particles from the steelmaybe no completely, but close enough to completely.
} 
Imaizumi was advocating the introduction of this method into Japan from early on. As early as June 1927 he was making his view on the matter known publicly. ${ }^{21}$ The reason he took notice of the new method, however, was not the same reason it was being used so widely in Germany. It was not because the iron ore being used in Japan was so high in phosphorus. What attracted Imaizumi to the new method was the fact that scrap iron could be dispensed with at the steel manufacturing stage if one used such a converter, and also the fact that savings could be made on fuel. Furthermore, if one used the Thomas method one could obtain "Thomas fertilizer" (the phosphorus in the slag), and this would enable one to lower steelmaking costs even more. The one sticking point, however, was that Thomas steel was inferior to open-hearth steel in quality. Still, according to Imaizumi's way of thinking, a situation in which one is dependent upon only the open-hearth process, as was the case in Japan at that time, was itself irrational. Imaizumi's views on the situation during that time are best expressed in his own words; the citation is rather long, but I would like to quote it here because it fits neatly within the context of this discussion. ${ }^{22}$

In all the countries in the world the great majority of objects that people in the steel manufacturing industry try to produce are "ordinary carbon steel products." In our country in particular, because the development of machine manufacturing and other high-grade processing industries is insufficient, the great majority of demand is for ordinary carbon steel products. Now, on the present level of the science of steel manufacturing, the method by which such steel products can be obtained at the cheapest cost is the Thomas steel manufacturing method. There is nothing that can equal it... [Meanwhile,] the steel manufacturing industry in our country is continuing to produce almost solely by the open-hearth steel manufacturing

${ }^{21}$ Kaichirō Imaizumi, "Doitsu seikō jigyō no fukkō to wagakuni ni okeru Tōmasu seikōhō no susume" [The revival of German steelmaking operations and a recommendations of the Thomas steelmaking method in our country], in Kiichirō Matsushima, ed., Tōmasu seikōhō [The Thomas steel manufacturing method] (Chikuma Shobō, 1943).

${ }^{22}$ Kaichirō Imaizumi, "Wagakuni seikōgyō no gōriteki sasshin to hiryō seisaku" [A rational renovation of our country's steel manufacturing industry and fertilizer policies], in K. Imaizumi, Tetsukuzu sh $\bar{u}$ [Steel scrap gatherings], pt. 2 (Kōseikai Shuppanbu, 1930), pp. 1064-65. 
process, it continues to put on the market the products of this expensive steel manufacturing process, which is geared to producing only steel of superior quality, and it continues to compete unconditionally against the lower costs of the ordinary steel products that are produced in various countries in Europe by means of this Thomas steel manufacturing method, as a result of which it continues to oppose the import of those products, at the same time barely maintaining its own operations.

What he was saying, in other words, was that, if the desired orientation is to ordinary carbon steel products, which account for the great majority of steel products demand, then Thomas steel can be used for that purpose, and from a cost standpoint this would be more advantageous than open-hearth steel.

In October 1934, when the government granted approval of Nippon Steel Pipe's submission regarding its first blast furnace, Imaizumi and Shiraishi were presented with a document called "Adoption of the Thomas Steel Manufacturing Method and Its Advantages." ${ }^{23}$ The following year Shiraishi mentioned the name of the Thomas method and argued the necessity of a steel manufacturing method that had as its principal raw material pig iron. ${ }^{24}$ In July 1936 (the year after the first blast furnace had been completed) Shiraishi sent technicians to Europe to conduct on-the-spot studies of the Thomas method, and in a very short time (in October 1936) a formal contract was entered into with the German steel machine manufacturer, Demag Company, placing orders for Thomas converter machinery. ${ }^{25}$ The company began construction of three 20-ton (referring to the amount of steel that could be produced in a single operation) Thomas converters in June 1937, and by June the next year construction was completed and the converters were put into operation (a Thomas fertilizer plant was also put into operation). In the operations, of course, the guidance of technicians was necessary, and the company employed one German engineer and four German mechanics. ${ }^{26}$

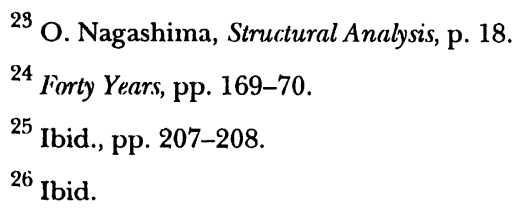


As well, in these operations Imaizumi was putting some of his own ideas into the process of manufacturing the pig iron used in these converters. As I mentioned earlier, the Thomas converter was a steel manufacturing method that was able to remove phosphorus particles at the steel manufacturing stage; now, since these phosphorus particles were at the same time a source of heat, it was necessary for a certain amount of phosphorus particles to be contained within the pig iron used in the converters. But because Japan lacked a good supply of phosphorus-bearing iron ore, the amount of phosphorus contained in its pig iron was unsufficient. So what Imaizumi thought of was a method of producing phosphorus-bearing pig iron for use in the Thomas converters by packing phosphate rock into the blast furnaces. ${ }^{27}$

The introduction of a converter steel manufacturing process like this that needed no scrap iron was, as Imaizumi and Shiraishi had foreseen, to prove its effectiveness during the restrictions on imported scrap iron that occurred later. The amount of scrap iron imported into Japan began stagnating from 1937; it peaked in 1939, then fell dramatically. The reason was that imports from the United States, Japan's principal source of scrap iron imports, at first stagnated when relations between the two countries deteriorated, then fell. ${ }^{28}$ Then in October 1940 the United States finally enforced an embargo on exports of scrap iron to Japan. The volume of scrap iron purchases by Nippon Steel Pipe also reached a peak in 1939, only to plunge in 1941 to a mere one-third of what they were at the peak. ${ }^{29}$

To cope with the shortage of scrap iron, Nippon Steel Pipe immediately increased the volume of production of pig iron used in its Thomas converters in order to step up the level of use of the converters. That is, whereas at the time the company began operating the converters it was using only one blast furnace to supply the pig iron for the converters, from May 1940 it began using another blast furnace for the converters, and then in October 1940, after the imposition of the United

${ }^{27}$ Kaichirō Imaizumi, "Enkisei tenro seikōhō [tsūshō Tōmasu seikōhō) no kaishi ni tsuite" [On the start of the basic converter steel manufacturing method (what is called the Thomas steel manufacturing method)], in $\mathrm{K}$. Matsushima, ed., The Thomas Steel Manufacturing Method, pp. $62 \mathrm{ff}$.

${ }^{28}$ See Steel Industry Reference Materials (cited in n. 19 above), pp. 240-41.

${ }^{29}$ Forty Years, p. 859. 
States embargo on exports of scrap iron to Japan, it added yet another blast furnace. It also increased by two the number of its converters. ${ }^{30}$ As a result of these measures the output of converter steel increased rapidly (from 150,000 tons in 1939 to double that in 1941, to reach a peak of 350,000 tons in 1942). From 1942 on, converter steel accounted for approximately half of the steel ingot output of Nippon Steel Pipe's Kawasaki Iron and Steel Works. ${ }^{31}$

Along with the expansion in its production of Thomas steel, the company was forced to put some effort into removing a sort of "prejudice" that existed at the time against Thomas steel within the industry in general. And so it carried out comparative studies in its Technical Research Division into the qualities of open-hearth steel and Thomas steel, and, on the basis of the objective data obtained, set out to improve what it called "insufficient knowledge about Thomas steel." Thus, for example, the technicians in the Technical Research Division carried out studies comparing the qualities of Thomas steel with the open-hearth steel generally used in rolled steel products and examined the differences in mechanical qualities of both; from the results of their studies they were able to report that

While Thomas steel of approximately $40 \mathrm{~kg} / \mathrm{mm}^{2}$ tensile strength had a slightly higher content of $\mathrm{P}, \mathrm{N}_{2}$, and $\mathrm{O}_{2}$ than open-hearth steel, we can state that there is almost no inferiority to open-hearth steel when it comes to its mechanical qualities.... Our conclusion is that, if Thomas steel is found to meet the standards for rolled steel products set down in the Japanese Industrial Standards legislation, then there is no real reason why it cannot be used without any distinction between it and open-hearth steel. ${ }^{32}$

Their efforts bore fruit, for after that the Thomas steel standards were gradually added to the official standards, and use of the steel continued to spread. ${ }^{33}$ The reason why, after the end of World War II, Nippon

${ }^{30}$ Ibid., p. 645.
${ }^{31}$ Ibid., p. 755.

${ }^{32}$ Kōsuke Kikuchi and Takehei Iwafuji, "Tōmasu kō to heiro kō no zaishitsu hikaku kenkyū" [Studies comparing the qualities of Thomas steel and open-hearth steel], in The Thomas Steel Manufacturing Method, pp. $107 \mathrm{ff}$.

${ }^{33}$ K. Kikuchi, "Tōmasu kō ni yoru seihin narabi ni yōto" [Products of Thomas steel and their usage], The Thomas Steel Manufacturing Method, pp. 107ff. 
Steel Pipe very quickly took notice of the LD converter and was, along with Yawata Iron and Steel Works, a pioneer in Japan in using that type of converter, was that the Thomas converter and the LD converter "in many respects shared technological continuity."

\section{CONCLUSION}

We have seen, analyzed, and discussed the technology choice problem faced by Nippon Steel Pipe under the wartime regime as an enterprise action adopted by the company to cope with the problem of supply of the raw materials used in steel manufacturing. Considering the matter this way, we are, I feel, able to conclude that this enterprise action was, in the last analysis, a rising to the challenge presented by weaknesses existing within Japan's steel manufacturing industry itself before the war: the imbalance between pig iron and steel, and the problem of scrap iron. The only reason Japan's steel industry as a whole was able to overcome these problems was that, after the war, Yawata Iron and Steel Works, Fuji Iron and Steel Works, Nippon Steel Tube, and the other powerful steel manufacturers aimed at integrated pig iron and steel operations and then all the integrated manufacturers went ahead with the introduction of LD converters. If one looks for the special features of Japan's postwar steel industry in terms of the construction of littoral-type integrated pig iron and steel plants and a shift to the LD converter steel manufacturing method, then I feel Nippon Steel Pipe can justifiably be said to have acted as the prototype of these features already in the period before the war.

\footnotetext{
${ }^{34}$ Yūshi Enta, Inobeeshon no honshitsu-tekkō gijutsu dōnyū purosesu no Nichibei hikaku [The essence of innovation: A comparison between Japan and the U.S. of the process of introducing steel manufacturing technology] (Tōyō Keizai Shinpōsha, 1986), 0.100 . (This book is a translation of the book by Leonard H. Lynn.) There are works by Nippon Steel Pipe technicians who were actually involved in the introduction of LD converters: Tsuneo Kinoshita, "Nippon Kōkan ni okeru seikōhō no suii gaikyō ni tsuite" [General fluctuations in converter steel manufacturing methods at Nippon Steel Pipe], Tetsu to hagane [Iron and steel], 1960, no. 7; and Jō Doi, Nippon Kōkan ni okeru tenro seikōhō no ayumi [The history of converter steel manufacturing methods at Nippon Steel Pipe] (Nippon Steel Pipe, 1987).
} 